\title{
Allawah Grove Native Settlement: Housing and assimilation
}

Sharon Delmege

It is well known that the rationale for state intervention in the lives of Indigenous Australians performed a volte face when 'assimilation' was adopted in 1937.' By the 1960s, 'integration' had emerged as a preferred guiding principle, but the goal remained the same: to incorporate Aborigines within the broader community as self-directed social and economic equals. However, a fundamental lack of respect for Aboriginal culture, combined with the idea that 'part-Aborigines' had no cultural heritage, ensured that Aboriginal identity, agency and autonomy were largely ignored. ${ }^{2}$ Since then, we have witnessed shifts to 'self-determination', 'reconciliation' and to 'closing the [health and well-being] gap', but there is still a long way to go before any of these principles are fully achieved.

In this paper, I draw on the case of the Allawah Grove Native Settlement (19571969), Perth, to demonstrate the gap between a policy that dangled the promise for a better life and its implementation, in which that promise played out as hollow rhetoric. Since Allawah Grove is usually referred to in terms that indicate a failed experiment in assimilation, I take this opportunity to reframe this legacy and argue that it was a missed opportunity in housing policy. ${ }^{3}$ This paper

\footnotetext{
1 Adopted at the first Native Welfare Council (NWC) in 1937, affirmed at the third conference in 1951 as the aim of native welfare, and defined at the conference on Australia Day in 1961.

2 Keen 1988: 1; Berndt and Berndt 1979: 87; Rowley 1972.

3 Hasluck saw Allawah Grove as a legacy of missed policy opportunities to include urban Aborigines within the community in the 1930s. Hasluck 1988: 76; Howard 1981: 32-33; and Haebich 2008: 257-259 provide nuanced perspectives in terms of Aboriginal political activity and assimilation respectively. For references to Allawah Grove in terms of local history and reserves see Carter 1986; SWALSC et al. 2009: 297; Department of Indigenous Affairs 2003: 70-71, 99. For biographies, lifestories and oral histories see Beresford 2006: 49-50; Bropho 1980: 35-42. See Walley and Pushman 2005 for a photographic commemoration of the achievements at Allawah Grove.
} 
contributes to existing knowledge of urban housing and to the historiography of governance and resistance by outlining its administration. ${ }^{4} \mathrm{I}$ argue that although Allawah Grove existed as the only non-institutional housing community in Western Australia, due to the state's adoption of an assimilation policy in 1948, the state did little to provide the conditions of possibility for Aborigines to be included within the broader community as autonomous social and economic equals.

\section{The Allawah Grove site}

The isolated site in South Guildford, on the north-west corner of Perth airport, had a long association with Aborigines who self-identified as 'campies' ${ }^{5}$ It was first gazetted in 1910 as the reserve for Aborigines, but was cancelled in 1917 because 'campies' resisted all efforts to be moved. When they were forcibly removed to the site in the 1930s, they refused to stay. The site was regazetted in 1941 and 'campies' were sent again, but it was appropriated by the Department of Defence almost immediately and the 'campies' were returned to their longstanding camps in Eden Hill. ${ }^{6}$ The site was transferred to the Commonwealth after the war, and the Commissioner of Native Affairs, Frank Bray, was approached to adapt the buildings for an Aboriginal community. ${ }^{7}$ But like previous Protectors, he was philosophically opposed to Aborigines living in Perth. The State Housing Commission used it instead as emergency housing for 'white people' until it was condemned as a 'fresh-air slum and hell hole' in 1957. ${ }^{8}$ By then, a new Commissioner for Native Welfare, Stanley Middleton (1948-1962), had adopted the policy of assimilation and, as an advocate of equal civil rights, he removed travel restrictions. As a result, the Aboriginal population in Perth quickly doubled to about 700, but the private rental market was still largely closed to Aborigines or charged a premium for the privilege of poor accommodation, and there was no official access to public housing. ${ }^{9}$ Many families were therefore forced to share overcrowded, derelict accommodation with extended family, and another 300 people camped or slept under bridges trying to avoid the police. ${ }^{10}$

\footnotetext{
4 Delmege 2000, 2014; Haebich 2005, 2008: 254; Hasluck 1988; Rowse 2005; Barwick 1964; Gale 1964; Gale and Wundersitz 1982; Wilson 1964; Morgan 2000: 190; Manning 2005: 225; Langton 1981; Rowley 1972; Howard 1981: 98.

5 State Records Office of Western Australia (hereafter SROWA) Con 993, 1937/0105. Reserve no. 12720. SROWA Con 993, 1931/0158: 109, 130, 144. Western Australia. Commissioner of Native Welfare, Annual Reports (hereafter CNW, AR) 1959: 28. Rowley 1970: 395-397; Hodgson 1989: 74.

0 CNW, AR 1957: 91.
} 
The Department of Native Welfare (DNW), and an Aboriginal organisation known as the Coolbaroo League, had been trying to find a housing solution since 1954. When they learned that the site was in the electorate of the Minister for Native Welfare, John Joseph Brady (1956-1959), he made a 'gentleman's agreement' with the ministers for Housing and Civil Aviation to take over the lease. This stop-gap housing measure was designed to last until, the lease expired on 30 June 1959, alternative housing became available, or the site was resumed to extend Perth airport. ${ }^{11}$ In other words, within a climate of social change that demanded a housing response, Allawah Grove began as a palliative, temporary measure to provide Aborigines in the metropolitan area with desperately needed accommodation. Ironically, this most minimal acknowledgement of urban Aboriginal disadvantage achieved what decades of segregation policy had been unable to do, which was to remove metropolitan 'campies' to a single location. It did not, however, stop local opposition to an Aboriginal presence in the area.

To his credit, Minister Brady was more interested in minimising Aboriginal frustration and the resentment that accompanied government interventions, than with local opposition. He and the Coolbaroo League recognised the need to maximise Aboriginal participation and agency, but this extended only as far as George Harwood, who was the new President of the Coolbaroo League and an officer in the DNW. As an Aborigine, he was seen as a legitimate representative to liaise between the organisations as they determined how Allawah Grove would be managed. ${ }^{12}$ The League began as an autonomous local Aboriginal organisation (1946-1960) that advocated civil and political rights, established a youth group, the first business in the CBD, an Aboriginal newspaper (Westralian Aborigine), and regular dances that were hugely popular. ${ }^{13}$ It had recently come under the umbrella and increasing influence of the Native Welfare Council (NWC), which had been established by Middleton in 1952 to coordinate middle-class wadjela organisations concerned with Aboriginal welfare. The NWC would play, as I shall show, a key role in the administration of Allawah Grove throughout the decade, largely due to the President, Cyril Gare. Like other NWC-affiliated organisations at the time in Perth, the League was therefore also committed to working with government departments 'to promote the welfare and assimilation of Aborigines'. In the absence of the Commissioner, who was on leave, they reached an agreement on 5 November. The Minister agreed to provide a fixed subsidy for utilities and the League agreed to take on the onerous terms of administration from 1 April 1958. This included property maintenance, improvements, providing for tenants' well-being and managing behaviour,

11 Daily News, 28 November 1957: 20; SROWA Con 1733, 1963/0116; CNW, AR 1959: 27; SROWA Con 993, 1957/0515: 25.

12 CNW, $A R$ 1958: 6.

13 Kinnane 2003: 339-342; Haebich 2008: 286-290. 
subject to ministerial oversight, all without any authority to enforce tenancy or ability to raise funds. ${ }^{14}$ From the outset, they had little chance of meeting the terms of their agreement, let alone their social and cultural aspirations.

To clarify the magnitude of their task, when the first eight 'huts' were transferred to the Department in November 1957, the site was in an appalling state. The ablution blocks had been demolished; there were no hot water heaters, window panes or flyscreens; sanitation was largely inoperative and it took weeks for the water to be connected. ${ }^{15}$ But 'campies' from Bassendean and Eden Hill embraced the opportunity because they just wanted a roof over their heads and somewhere to stop, without police harassment. Demand was such that by February 1958, there were 29 families or 220 people, including 28 who held citizenship. ${ }^{16}$ Most residents shared extended kinship ties and many moved between households at Allawah Grove and elsewhere, but among the first and longest-standing were members of the Blurton, Bodney, Boundary, Bropho, Clarkson, Edgill, Kickett, Moggridge, Moore, Nettle, Parfitt, Pickett, Quartermaine, and Yarran families, and Granny Anderson who had survived autonomously for decades in the metropolitan area. ${ }^{17}$

\section{Coolbaroo League administration, April 1958 - 30 June 1959}

When the Coolbaroo League took over, four months later, the brittle, unlined asbestos 'huts' were still in disrepair, there was little working sanitation and the refuse collection was woefully inadequate. The small huts, comprised of just a kitchen and two rooms, were always inadequate for family living. Poor sanitation was an ongoing issue that was exacerbated by damage and incorrect use, but every administration failed to have all the old, broken plumbing replaced by the Public Works department. However, in a pattern that continued throughout the decade, government agencies, charities and volunteers provided a combination of long-term services and ad hoc assistance. ${ }^{18}$ The most important of these were provided by Public Health, which appointed a nurse and underwrote renovations to a hut for a clinic, and the Victoria League, which subsidised renovations for a preschool. The Original Australian Progress Association (OAPA) and the NWC provided a broad range of vocational and

\footnotetext{
SROWA Con 993, 1957/0515: 14-26, 39.

CNW, $A R$ 1958: 6; Clements 1989: 27-28.

Clements 1989: 29; SROWA Con 993, 1957/0515: 10; SROWA Con 1733, 1959/0187: 62; CNW, AR 1960: 17.

Clements 1989: 30.

SROWA Con 993, 1957/0515: 25; CNW, AR 1958: 6.
} 
recreational activities and several churches met requests for services. ${ }^{19}$ Initially, the DNW funded a preschool teacher and a resident caretaker, Ollie Kickett, and Minister Brady encouraged residents' interest in a library and recreational hall. ${ }^{20}$

Brady and Middleton were publicly supportive of the League throughout 1958. The Minister responded to a parliamentary question, 'what interest have the residents taken in welfare of the area', by listing their achievements:

Some nine or ten truckloads of rubbish were removed ... when they first moved in. A basketball court is being prepared and many of the residents have established grass lawns ... nine months ago many of these people were living in abject poverty on the ground in miserable iron and bark humpies ... More important than the welfare of the area is the welfare of the people. ${ }^{21}$

The welfare of the people was important to Brady, and he did want Allawah Grove to 'become a major [project]', but he assumed that this would involve the League extending its activities rather than the Department. Middleton's Annual Report is also optimistic:

Broadly, there has been great improvement in their outlook, self-reliance and contentment ... it is appreciated that people take a long time to change their outlook and way of living. Given time, encouragement and opportunity it is possible for these people to become satisfactorily integrated into the community. ${ }^{22}$

But privately, Brady was already frustrated by the tenants' lack of economic and social 'progress' toward 'satisfactory integration'. Middleton was philosophically opposed to any form of segregation and would not have agreed that Allawah Grove was an opportunity to advance the assimilation of Aborigines in Perth. ${ }^{23}$ However, they took it for granted that assimilation or 'satisfactory integration' was dependent upon regular employment and rental payments, and it was assumed that the accommodation of wadjela behaviour and values was as inevitable as the loss of Aboriginality this would entail. Since steady employment underpinned the entire project, the lack of opportunities in Perth was a major issue. The League shared the Department's aspirations for equal citizen rights, because they wanted to see all Aborigines treated with respect and recognition, but had no uniform Aboriginal aspiration or position to draw upon. ${ }^{24}$ Citizenship offered the conventional avenue to achieving inclusion and 'respectability'. It did not follow that achieving 'respectability' resulted in the loss of Aboriginality, but others, for whom equal citizen rights represented

19 SROWA Con 1733, 1959/0198: 33; SROWA Con 993, 1957/0515: 7.

20 SROWA Con 1733, 1959/0186; 1959/0198; 1959/0187; 1963/0116.

214 September 1958, SROWA Con 993, 1957/0515: 10.

22 SROWA Con 993, 1957/0515: 29; CNW, AR 1958: 6.

23 CNW, AR 1958: 6.

24 Morgan 2000; Manning 2005: 221-235; Gale 1964: 107, 114; Rowse 2005: 54, 64, 66. 
the legitimacy of their identity, resisted assimilation. Therefore, while the Coolbaroo League assumed that the opportunity to live in houses would provide 'campies' with the long-term benefits of improved living standards, they did not anticipate immediate changes to residents' social or economic behaviour. ${ }^{25}$ Residents' opinion mattered little. As 'campies' they were resilient and used to accommodating wadjela values to suit themselves. The idea that 'satisfactory integration' could be achieved by changing 'their outlook and way of living' with 'time, encouragement or opportunity' misses the point. It was soon apparent, however, that these residents would be accorded little time, encouragement or opportunity.

The importance of unemployment throughout the decade cannot be overestimated. Middleton understood that Aboriginal families came to Perth because the rural labour market had evaporated. ${ }^{26}$ But other than seasonal work and casual domestic labour, there was no work in Perth for unskilled Aboriginal workers. The lack of employment opportunities in Perth was invariably presented as though it was just a 'nuisance' for state and local governments, but it was always a major issue for Aborigines. ${ }^{27}$ It also posed a significant problem for the League since it depended on rental payments to meet the terms of its agreement. Complaints about the behaviour of unemployed men added to that pressure. Drinking, gambling and fighting were commonplace and were equally enjoyed, ignored and frowned upon. In this instance, residents called for a petition to remove the worst offenders, but the League had no authority to enforce evictions for non-payment of rent or 'bad behaviour'.$^{28}$ Frustrated, Brady decided to bypass the residents and the League and ask Middleton to take control. ${ }^{29}$

Harwood responded by urging the Department to make serious provision in its budget estimates for significant material improvements that included basic sanitation and fences to keep uninvited people out. In a lengthy, diplomatic attack on passive welfare, he also roundly condemned previous policies for creating 'pauperised scavengers and parasites', and recommended exposing individuals to the consequences of their behaviour. ${ }^{30}$ His suggestions to hold both the state and residents to account were ignored, and this did not alter with the change of government on 21 March. Middleton's advice to the new minister, C. C. Perkins, was that residents were better off at Allawah Grove than in their

\footnotetext{
25 Barwick 1963: 326-327 in Rowse 2005: 66 shows a parallel trend in Melbourne.

26 Rowse 2005: 66.

27 Soil was too poor for market gardening and residents did not have the skills to manage a cooperative venture.

28 SROWA Con 993, 1957/0515: 16-26.

29 CNW, $A R$ 1959: 24.

30 SROWA Con 993, 1958/0321: 49-54. See also Pearson 2000.
} 
camps and that they should leave the League in charge. ${ }^{31}$ By recommending the status quo, the League had no option but to ask the DNW to take over in May. They had made improvements after an embarrassing health report in March, but there were still too many outstanding sanitation issues. ${ }^{32}$ In addition to 30 occupied huts, a family of seven lived in a disused laundry, two adults slept under a hut, and there was one camp of four adults. Fifteen huts had pans that were serviced twice a week and 18 had septic systems that still had problems with the tanks and drains. All ablutions were outside, only 12 huts had hot water, four had no water at all, none had window panes or fly screens and many had been waiting months for asbestos sheets to repair walls.

The Daily News was quick to claim credit for the change in administration, declaring that their exposé had revealed how the 'bold experiment - a housing settlement for natives, run by natives - had degenerated into something close to chaos'. ${ }^{33}$ They cited the resident caretaker, who was powerless to remove 'squatters and hooligans', white and black, because there were no fences; a representative from Social Services, who blamed boredom, unemployment and Child Endowment; and a Native Welfare Councillor who blamed a minority for transforming the settlement into a sordid centre for unbridled drinking, gambling and prostitution'. ${ }^{34}$ The lack of fences was an issue that could have been addressed had the DNW the funding or inclination to assist. Given that Aborigines were only granted full access to welfare payments in 1960, it is unsurprising that bored, underemployed people used it to party. Minister Perkins' immediate promise of 'stricter control' over the 'temporary' facility was a simplistic response to a complex issue and publicly marked a shift in official attitudes. The DNW's more measured response was to provide two policy responses. It would remove metropolitan evictees, including those from Allawah Grove, to a 'native reserve'. 'Satisfactory tenants' would, eventually, be provided with alternative accommodation when the airport's extensions made 'existing quarters untenable'.$^{35}$ In the interim, Middleton invited the League to continue their 'welfare work for the inmates' and handed control to District Welfare Officer Bruce McLarty. By 30 June, McLarty was ready. He had made basic repairs and introduced tenancy agreements, but the language and tactics used 'police assistance', daily patrols and one-way tickets to remove 'squatters' and other 'undesirables' - reveal traces of the paternalism that previously attended their segregation policies. ${ }^{36}$

\footnotetext{
9 April 1959, SROWA Con 993, 1958/0321: 64-5.

12 March, SROWA Con 1733, 1959/0186: 26; 5 April 1957, SROWA Con 993, 1957/0515: 69, 71-73, 83.

Daily News, 19 June 1959, SROWA Con 1733, 1963/0116.

Daily News, 2 June 1959: 1; SROWA Con 1733, 1963/0116.

SROWA Con 1733, 1959/0187: 32; SROWA Con 993, 1957/0515: 77, 87-88.

SROWA Con 993, 1958/0321: 87-88, 94; SROWA Con 1733, 1959/0186: 34; CNW, AR 1959: 29; 1960: 17.
} 
However, the Department was quickly forced to reverse its plans. There would be no native reserve due to the intense opposition of white residents living in the neighbourhood of places selected ... and the objections raised by Local Authorities'. ${ }^{37}$ The DNW would instead house 'selected families ... in existing residential areas'. The 'residue of natives' was to be left at Allawah Grove, which would function as 'a native reserve' until they were 'forcibly ejected', at which point they would be returned to the country, or 'to the conditions which existed before Allawah Grove'.$^{38}$ On this basis, the Department renewed the lease until 1 August 1960 and on a monthly basis thereafter. ${ }^{39}$ The only recognition of Aboriginal disadvantage is this extract from a lengthy outburst by Middleton, which reveals his utter dismay at the ongoing lack of housing options:

natives were not wanted anywhere in the metropolitan area 50 years ago, and they are not wanted today; for 50 years attempts to provide them with a sanctuary have been successfully obstructed by white residents of the district concerned, backed up by local authorities ... The situation in most material respects remains substantially the same today as it was in 1908. There are no grounds for believing that there will be any appreciable change in the foreseeable future ... [despite] the immediate and urgent need of the majority of native families who cannot afford to build, buy or rent cottages. ${ }^{40}$

However, it is clear that Middleton had also decided to make accountable those who did not take advantage of the opportunity to live like mainstream Australians. The idea of assimilation was a remarkable turn from the Department's previous position, but it was another Aboriginal policy without funding. Official policy therefore extended little further than the idea that Aborigines should be encouraged to assimilate. Yet having created a class of fringe-dwellers in the south-west, the state not only had an obligation, but an opportunity to support the conditions of possibility for Aborigines to improve their health and well-being. ${ }^{41}$ However, the Department had neither the funds nor the insight to take advantage of the opportunity that Allawah Grove presented, and they were never held to account.

37 SROWA Con 993, 1957/0515: 87.

38 SROWA Con 1733, 1959/0198: 24; 26 June 1959. SROWA Con 993, 1957/0515: 93.

3929 June 1959, SROWA Con 993, 1957/0515: 89, 108.

40 CNW, $A R$ 1959: 28.

41 Delmege 2005. 


\section{The Department of Native Welfare's administration, July 1959 - June 1960}

McLarty began what he assumed would be a short administration, with a population of 134 tenants and 13 authorised visitors. Overcrowding was a key feature, with 11 of the 27 huts housing large families of six to 10 people, plus their authorised visitors. Minister Perkins had begun negotiations to send the best tenants to vacant State Railway houses, but they found accommodation elsewhere and left before he was ready. The remaining tenants had little to no experience with rental accommodation. ${ }^{42}$ Middleton did not underestimate their difficulties in meeting the social and economic requirements for tenancy, and suggested the new 'transitional' housing that was, ostensibly, better suited to 'less assimilated Aborigines' ${ }^{43}$ But metropolitan councils would only allow conventional housing. While the State Housing Commission was building 30,000 houses to accommodate post-war immigrants, it had only built one house under the federally funded Native Housing Scheme, at Bayswater. In other words, the state failed to recognise urban disadvantage and the legitimate aspirations for decent housing. Consequently, the waiting list for families who were 'financially and socially eligible' for such housing was already long and growing - residents at Allawah Grove had no chance. ${ }^{44}$ The point is that there were no housing options in the metropolitan area for 'satisfactory tenants' at Allawah Grove, let alone those evicted. However, the Department had no intention of making any long-term plans for Allawah Grove, despite the excuse that it had no tenure. ${ }^{45}$ McLarty began to reduce the population and after disposing of 13 empty huts that were a 'standing invitation to squatters', he put the hall to tender in January. ${ }^{46}$ Shortly afterwards, the Department learned that the site would not be needed for at least three years, if at all, but it was already committed to closure. From its perspective, the time and money allocated to Allawah Grove was disproportionate and worthless because residents had not 'improved' their economic and social behaviour. ${ }^{47}$ It is true that the DNW spent more on this group than any others in the state, but this needs to be put in perspective. Under Middleton, the budget to improve living conditions across the state had grown from $£ 0$ in 1948 to $£ 7,000$ in $1957 .{ }^{48}$ This provided a tap and toilets to half the 61 camping reserves; a third with two showers, a copper and a trough; and

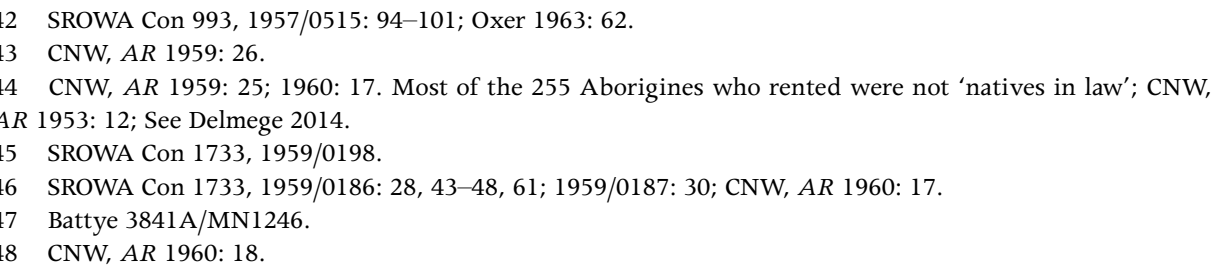


just six rudimentary dwellings. ${ }^{49}$ Against such meagre standards, tenants were lavished with services, but against the standards required of a 'satisfactory' tenant, they were unfairly burdened with proving themselves worthy of basic amenities. At a time of high unemployment and homelessness, the idea that the DNW could just close the facility without regard for the consequences is breathtaking.

After initial disbelief, Cyril Gare responded by proposing that the Native Welfare Council (NWC) take over. ${ }^{50}$ At a meeting at Mary Durack's house to discuss the situation, some argued that Allawah Grove was not an ideal vehicle for 'rehabilitating ... and encouraging assimilation', but all agreed that its closure would see residents gravitate to East Perth and 'into the company of the most undesirable elements of our white society'.$^{51}$ The renowned anthropologist Dr Ronald Berndt wanted to encourage assimilation, and prevent the formation of suburban colonies, by placing just two to three families per suburb, near facilities and with the support of a social worker. However, Gare was confident that the NWC could achieve 'reasonable health, education and responsibility' and provide a model for all of Australia. ${ }^{52}$ To this end, he brought the glare of publicity to bear and played the assimilation card to ask for the opportunity to use Allawah Grove as a 'training centre' to 'prepare tenants for integration into the general community' ${ }^{53}$ The Department was highly sceptical, but since there were no housing alternatives, the Minister invited the NWC to supervise all aspects of tenancy, and agreed to maintain and administer the Grove. However, he flatly rejected their call for full financial support and welfare workers, but without adequate funding, the NWC was loath to repeat the Department's half-hearted, palliative effort. ${ }^{54}$ They capitulated eventually, on 16 June, but only to avoid the imminent closure and dispersal of residents. ${ }^{55}$ What is glaringly absent from the debate is the residents who were spoken for, as though they were wayward minors in need of rehabilitation, support and protection, because their speaking position was conflated with an Aboriginal identity that remained the province of white expertise.

\footnotetext{
49 CNW, $A R$ 1957: 14-23; SROWA Con 1733, 1959/0187: 62; CNW, AR 1960: 9, 16-17; Battye 3841A/ MN1246; Gare 1989: 35.

50 Gare to Perkins, 15 March, Battye 3841A/MN1246; CNW, AR 1960: 18.

51 Oxer 1963: 70-71.

52 Berndt debated whether successful assimilation involved individual achievement at the expense of social ties. Berndt 1962: 78-81; Battye 3841A/MN1246. Gare worked at MacRobertson Miller Airlines (MMA), founded by Durack's husband, Horrie Miller.

53 Weekend Mail, 30 April 1960: 4; Sunday Times, 7 April 1960; CNW, AR 1960: 18; Battye 3841A/MN1246.

54 CNW, AR 1960: 18-19.

55 Weekend Mail, 21 May 1960: 2, Battye 3841A/MN1246.
} 


\section{The NWC and DNW administration, June 1960 - August 1961}

The Allawah Grove Committee (AGC) and the DNW shared responsibility for a year that was riven by disagreement and bad publicity. The seven-member committee, six of whom were middle-class white women, elected Cyril Gare chairman. With an eye to securing State and Commonwealth oversight and funding, they also co-opted another 12 members from relevant government departments. ${ }^{56}$ They generated public support by courting the press and they held 'busy bees' that attracted volunteers, including the future Minister for Aboriginal Affairs, Fred Chaney. They tried improving rental payments by replacing weekly trips to Perth with onsite collections on pay-day. But because most men were illiterate and unskilled, most achieved, at best, only casual employment and by August, 50 per cent of tenants were in arrears. ${ }^{57}$ With no appetite for evictions, the population increased rapidly and, along with overcrowding, poor health and bad publicity, relations with the DNW quickly soured.

Headlines such as 'Native camp seen as Health Danger' and 'Disease at the Grove' helped focus public attention on the appalling living standards at Allawah Grove. ${ }^{58}$ The latter stated that it 'was a breeding ground for gastro-enteritis and trachoma'. And so it was. Health problems were endemic. Trachoma was rife and there were always children in hospital with infectious diseases. ${ }^{59}$ But publicity invariably vilified residents rather than their living conditions. The public read that massive water wastage was due to wilful damage, rather than old plumbing and water mains. ${ }^{60}$ In the public debate that followed, District Officer McLarty freely admits his antipathy in this complaint to Middleton on 20 April:

Without exception, the natives at present domiciled there have failed to use it as an opportunity for improvement of their own social and physical circumstances and have unashamedly exploited it for all it was worth. This was patently obvious to me when I assumed responsibility for Allawah Grove in July 1959 and was the foundation of my policy of systematic closure. ${ }^{61}$

Relations between the NWC and the DNW broke down entirely in the first week of May. Initially, Gare was outraged that the Department had complained publicly about the cost of subsidising Allawah Grove. The AGC made the point that in 19 months, not one new tenant had been offered a hut in good order and

56 Battye 3841A/MN1246.

57 SROWA Con 1733, 1959/0187; 1959/0198.

58 Weekend News, 22 April 1961; The West Australian, June 1961, Battye 3841A/MN1246.

59 Clements 1989: 48.

60 SROWA Con 1733, 1959/0186; 1959/0187.

61 SROWA Con 1733, 1959/0186: 131. 
despite repeated requests for plumbing repairs, most new tenants had never had 'the luxury of a proper shower' ${ }^{62}$ Gare questioned the Department's accounting, lamented 'the hopeless pessimism' of many officers and reiterated that there had never yet been 'a properly planned and equipped effort' in Australia. ${ }^{63}$ Middleton was then quoted in The Bulletin saying that Allawah Grove 'had failed as a social experiment in the education of natives to the standards of urban living', and by week's end he threatened to close it unless the AGC showed an 'immediate change in attitude and tactics' ${ }^{64}$ The DNW had already made it clear that it would only assist those who could conform to white standards of living. That this was extremely difficult for large families living in small houses without working sanitation or plumbing was irrelevant, but it placed the AGC in the unenviable position of trying to keep Allawah Grove open and trying to achieve a higher standard of living in appalling conditions.

Consequently, a fortnight later Gare offered, on behalf of the NWC, to manage the Grove independently. ${ }^{65}$ Perkins' decision to accept, and to ignore Middleton's dissent, was undoubtedly influenced by national and international political pressures. ${ }^{66}$ Nationally, ministers and the Federal Council for Aboriginal Advancement were calling for Commonwealth oversight of funding for housing because there had been little progress since assimilation had been accepted in 1951. For the same reason, the Department of External Affairs was also exerting pressure because international criticism was damaging Australia's reputation. ${ }^{67}$ In this climate, Save the Children Fund took on Allawah Grove as its first Australian project and provided funding for the social worker they had waited so long for. But this was a missed opportunity to recognise urban disadvantage and the legitimate aspirations for decent housing and meaningful participation in housing choices and homemaking, by allocating adequate resources. ${ }^{68}$

\section{Allawah Grove administration, September 1961 - February 1969}

The 14-member Allawah Grove Administration committee (AGA) began with enormous goodwill, and was comprised entirely of wadjelas. They elected Cyril Gare chairman and Dr Lewis formed an Advisory Panel to provide expert

\footnotetext{
62 SROWA Con 1733, 1959/0186; 1959/0187.

63 Gare to Middleton, 1 May 1961, Battye 3841A/MN1246.

643 May 1961, Battye 3841A/MN1246; Middleton to Taylor, 8 May 1961, SROWA Con 1733, 1959/0186.

6517 May 1961, CNW, AR 1961: 28.

66 CNW, $A R$ 1961: 27-28; 1962: 29. Federal pressure saw WA Aborigines able to vote in State elections, one day before the Empire Games opened in Perth, 1962.

67 Taffe 1995: 170.

68 Milligan et al. 2011: 103. See also Milligan et al. 2010; Habibis et al. 2014, 2015; Sanders 2008.
} 
guidance. ${ }^{69}$ The Constitution stated that the AGA would provide one or more social workers along with adequate housing and technical training to establish 'a model training settlement as a step towards assimilation' ${ }^{70}$ Allawah Grove was financed by scheduled donations, which provided about half the running costs, periodic donations from the Victoria League and the Lotteries Commission, public donations, an annual street appeal and rent. The DNW maintained its fixed subsidies for utilities. The Executive held weekly meetings onsite, and some were involved in activities at the Grove, but Gare was a busy man with little inclination to consult the Executive or make contact with residents. His wife, Elsie, was on the Executive but she was also closely involved with the community throughout the decade. ${ }^{71}$

Elsie Gare instigated the Friends' Centre, where the women met each day. The name also alludes to the Gares' affiliation with The Society of Friends, or Quakers, who focused on social justice and finding practical ways to help others help themselves. Of the many activities, bark painting was a creative outlet that enabled Ruth Kickett to develop the expertise to become the teacher. It also created an income because they sold hundreds of pictures at tourist shops and at the many public talks given by the Gares. ${ }^{72}$ Proceeds from the weekly 'opshop' also subsidised the first kindergarten for Aboriginal children in Western Australia. The kindergarten and clinics were arguably the longest standing and most significant initiatives at Allawah Grove, and Margaret Clements was central to both as the kindergarten director and clinic nurse. Gwen Corunna recalled: 'we all knew Margaret Clements, she was just one of the sweetest persons that's ever been around, because her heart was just there for the children, for the people'. ${ }^{73}$ Teachers remarked on the difference the kindergarten made in preparing the children for school, and Clements also introduced many simple but effective actions to improve children's education. ${ }^{74}$ For example, school attendance and performance improved dramatically when the Save the Children Fund provided a school bus and materials for mothers to provide school uniforms. She also encouraged teachers to visit to help with homework and to learn about the connections between employment, health, housing and education, because many pupils had poor hearing due to ear infections from overcrowding, or lacked concentration due to late nights as adults partied or fought. The Education Department took on the responsibility for Aboriginal education in 1963, and their efforts to improve school attendance and achievement with broadbrush

69 Allawah News, September 1961: 4, December 1961-January 1962.

70 SROWA Con 1733, 1963/0116: 163.

71 Oxer 1963: 99-100, 114.

72 Clements 1989: 30; Walley and Pushman 2005: 35.

73 Walley and Pushman 2005.

74 Clements 1989: 30; Daily News, 18 July 1962; The West Australian, 16 October 1963: 25; SROWA Con 1733, 1959/0198: 60; Battye 3841A Allawah News, December 1961 - January 1962: 5. 
systemic remedies such as hostels and scholarships were clearly well overdue. However, they lacked the experience and cross-cultural understanding to avoid undercutting contextually appropriate initiatives. In the new inclusive paradigm, Clements' suggestion for an onsite school, to counter the ubiquitous playground racism, was rejected as 'paternalism' and her school-readiness testing program was later suspended on the grounds that it was discriminatory. ${ }^{75}$ Traditional knowledges were learned outside the classroom and beyond the bounds of administration. Vicki Boundary recalls: 'We were taught the culture, it was really strict ... sitting down listening to them when they used to take us to Monday's Swamp, all those little things you had to do with the turtle. ${ }^{.76}$ Donna Pickett also recalls: 'It was really solid. I think that's where we learnt to respect one another out there, 'cause everybody was our uncle and aunty or grandmother ... there was a lot of caring and sharing.'

Residents had little access to regular health care until Allawah Grove, so the clinics were important initiatives. From the outset, a local doctor provided a weekly adult clinic and free consultations at his practice. Dr Lewis attended the children's clinic with nurses and medical students to develop their awareness of illnesses, such as upper respiratory tract, skin and bowel infections, that were endemic to many Aboriginal communities. ${ }^{77}$ Clements assisted throughout the decade and later opened a clinic that was the forerunner to the Aboriginal Medical Service (1973). Robert Bropho wrote of the esteem in which she was held:

She was the black people's Florence Nightingale. I'll speak about her as a mighty lady ... who offered a lot of assistance to Aboriginal people, especially mothers and children living at Allawah Grove ... she'd be the white grassroots of all medical services that are in existence today ... we salute you, Mrs Margaret Clements. ${ }^{78}$

Despite these important initiatives, all efforts to improve health and education struggled in the face of overcrowding. In an effort to ameliorate this, the AGA offered tenants a 3:1 funding deal that provided a verandah as a sleep-out for families with at least six children. ${ }^{79}$ But overcrowding was driven by insufficient housing in Perth and increasing unemployment. With the rural labour market evaporating across Australia, Aborigines increasingly joined the urban drift in search of work and away from the appalling conditions on reserves and settlements. McClarty tried 'putting the brakes' on Aborigines coming to Perth

75 SROWA Con 1733, 1959/0198: 101; Clements 1989: 33; Allawah News, September 1963.

76 Walley and Pushman 2005: 43-44.

77 After 1963, other local doctors attended and encouraged attendance at their practices. Dr Lewis became Foundation Professor of Child Health at the University of Tasmania (1968-1988). SROWA Con 1733, 1959/0198:

45; Clements 1989: 45-47; Battye 3841A Allawah News, October 1963.

78 Bropho 1980: 38-39.

79 Battye 3841A Allawah News, December 1961 - January 1962: 5. 
when he denied the temporary relief routinely provided to new applicants for unemployment payments. ${ }^{80}$ But as suburban sprawl erased traditional camping areas, Allawah Grove became the staging place for Nyungahs arriving in Perth. The AGA asked the DNW for shelters to accommodate visitors at Christmas and the Royal Show, families who arrived for the grape-picking season or needed to come to Perth, but the Department's planning and funding focus remained with rural housing until the 1970s. ${ }^{81}$

The AGA's response to unemployment was quite different. Having observed the effects of unemployed men 'trudging about asking for jobs they knew they wouldn't get', they were concerned at the loss of potential leaders and wanted to improve their employment opportunities. This laudable motive for intervention was, however, underpinned by the assumption that in developing leadership skills and confidence they would also encourage a desire to 'assimilate ... into the white community' ${ }^{82}$ Allawah Grove presented a convenient opportunity to run pilot programs and the Adult Education Board accommodated them with a three-year program to develop literacy, family development, civic and economic skills. They also provided Des Davis and Lewis Boundary with scholarships in social studies to develop their leadership skills. While Toogood coordinated staff from teaching and technical colleges, the Health Education Council and employers, Des Davis was appointed Chairman of the Progress Association and represented Allawah Grove at the 1962 National Conference on Aboriginal Affairs in Adelaide. ${ }^{83}$ However, Davis and Boundary did not complete their scholarships because there was poor cross-cultural communication and they were poorly prepared for study and had little support from their employers. As a precursor to adult training that was offered statewide from 1965, this pilot clearly offered valuable learning opportunities. ${ }^{84}$ Toogood also tried other avenues to improve employment opportunities. He tried to establish a vocational wood and metal workshop, but the costs of installing a separate commercial meter were prohibitive, so he appealed directly to the public for regular employment opportunities. The AGA were sincere in their efforts to improve the employment opportunities of the men at Allawah Grove and by 1963 the majority of ablebodied men were in full-time or casual employment.

At the same time, the residents' Progress Association helped to create a community spirit and united voice. Toogood introduced the idea and it was heavily influenced by Gare's 'aided self-help' ethos, but it achieved much in

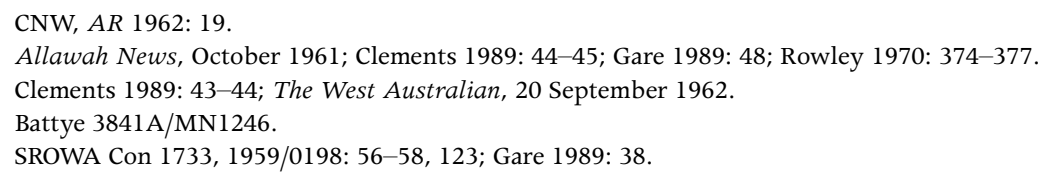


a short period ${ }^{85}$ Members elected an Executive, created a code of behaviour, introduced a savings club, supported sporting, recreational and educational activities, appointed a rent collector and produced a newsletter entitled Bebilwongai. ${ }^{86}$ Executive members such as Corrie Bodney, Des Davis, George Garlett, Lewis Boundary and Richard Kickett, among others, demonstrated the benefits of public speaking classes with regular public talks about their progress and the need for trained leaders and self-help, better education, housing and employment. ${ }^{87} \mathrm{~A}$ year after taking over Allawah Grove, the Committee therefore announced that the 175 residents at Allawah Grove had become 'a community ... where self-help and self-respect had become the ideals of its native inhabitants', with at least five families 'ready to move into the white man's housing estate' ${ }^{88}$ This was clearly designed to legitimise their efforts, but there was a marked reduction in gambling, drinking and fighting during this period, and although more tenants grew gardens, there was little they could do to improve the houses and the area never resembled a suburb. When the new Commissioner for Native Welfare Frank Gare (1962-1972) made a brief visit and was asked to contribute to Bebilwongai, he wrote:

Frankly, I was disappointed with Allawah Grove ... Certainly, there are some notable achievements - the kindergarten with its bright-eyed children being one, some well cared for houses and gardens being another - but on the whole the effect is one of neglect, indifference and apathy. And this in spite of the earnest help of a host of well-wishers and the expenditure of more money than any equivalent group of people in the state. ${ }^{89}$

Residents debated his remarks and decided to ask for proof that more money was spent on Allawah Grove than elsewhere in the state, because they had not seen it, and to inform him of the actual number of able-bodied men who were employed. ${ }^{90}$ But the Commissioner concluded 'that the main thing wrong with Allawah Grove was its menfolk' because there was 'money going begging'. He complained that they refused an opportunity from a 'reputable buyer of aboriginal artifacts' to make 'small simple things' to an 'authentic pattern', because they had no machinery. ${ }^{91}$ But this assumes, firstly, that these men did not have access to skills that were considered 'old' and apparently 'largely lost'; secondly, that no skill was required anyway; and finally, that despite the lack of skills required, traditional or otherwise, anything they produced

85 Battye 3841A December 1961 - January 1962: 7.

86 Allawah News, August - November 1962; Bebilwongai, March - April 1962, Battye 3841A/MN1246.

87 A visiting specialist in community development supports this. Allawah News, November 1961, May July 1962: 3; August - November 1962, Battye 3841A/MN1246.

88 The Sunday Times, 16 September 1962. See Allawah News, December 1961, May 1962; Allawah Grove Administration General Report, 31 August 1963.

89 Cyril and Frank Gare were second cousins. Bebilwongai, March 1962: 7-8, Battye 3841A/MN1246.

90 Bebilwongai, March 1962: 6.

91 Bebilwongai, March 1962: 7-8. 
had monetary value because it was 'authentic'. The lack of respect for, and the exploitation of, Aboriginal culture demonstrated here is entirely lost on him. The Commissioner also assumed that the men demurred because they felt 'justified in sitting down' due to past injustices. He therefore completely ignored the manners demonstrated in avoiding a direct refusal, and the possibility that it indicated a preference for learning vocational wood and metalwork skills in their workshop.

The issue that galvanised community spirit was when Toogood was sacked. He had been appointed to an ill-defined role and the competing expectations of being a social worker and superintendent. But when tenants protested the AGA's decision and were ignored, and the AGA revised the rules of the Progress Association, they realised the limits of their autonomy. ${ }^{92}$ As a direct result, the Progress Association lapsed and active protests turned to apathy and discontent. ${ }^{93}$ After 'three police raids on the two-up school', residents responded by saying that if they were not allowed to play two-up they would take up drinking again, and then the fights would start and the police would really have something to do' ${ }^{94}$ Oxer's interviews with members of the Executive, volunteers and residents reveal that many were critical of the AGA's high-handed approach. George Anderson said, 'Even here, whites tell us what we can do. We can't please ourselves wherever we are'.$^{95} \mathrm{Dr}$ Lewis was especially critical of Gare's leadership, accusing him of acting as a 'Great White God' by not allowing residents to make their own plans and mistakes. He was equally dismayed that the Advisory Panel was never consulted or called upon, other than to impress donors for the purpose of extracting money. ${ }^{96}$

The appointment of Peter Coleman as Superintendent in July 1963 had a profound effect on the community. He insisted on having the authority to evict residents and prosecute unauthorised visitors, if he was to limit overcrowding and manage poor behaviour. ${ }^{97}$ The AGA was still loathe to evict anyone. Clements recalls their dilemma: 'It always worried us ... because we could see the children we were working with suffering [from overcrowding]. But it worried us ... when they often had nowhere to go.' ${ }^{\prime 8}$ The AGA accepted his 'drastic measures' after one family was rehoused. Hoping that alternative housing would soon be available, they decided to focus solely on training eligible tenants for suburbia. For this reason, they closed the Youth Club to 'discourage lads and girls over school age from staying at Allawah Grove' because they wanted youth who were ineligible

92 Bebilwongai, March 1962: 6, Battye 3841A/MN1246.

93 Oxer 1963: 147-152.

94 Oxer 1963: 172.

95 Oxer 1963: 174

96 Oxer 1963: 141, 97-99.

97 Oxer 1963: 116; Gare 1989: 28; Allawah News, August 1963: 3.

98 Clements 1989: 47; Allawah News, August 1963: 3. 
for apprenticeships to go to the country. ${ }^{99}$ But from an evictee's perspective, 'if anyone was caught sleeping in a place overcrowding with other people, the police was allowed to arrest them' ${ }^{100}$ Homeless families therefore either took the risk, camped nearby in scrub or caused overcrowding elsewhere. Robert Bropho describes the consequences for his family, who camped outside Allawah Grove after their application to rent a vacant hut had been refused:

The results of laying in rain soaked rugs overnight, my youngest son Harvey took sick and was taken to hospital with pneumonia ... Aboriginal people who never had homes then used to watch for the sun to go down. They'd be forever watching the weather and rolling their rugs and bags and moving off the Allawah Grove premises under some thick trees and scrubs, breaking some bushes and putting them together to try to make some shelter from the rain. ${ }^{101}$

Tenants were encouraged to demonstrate their readiness for life in the suburbs, but the criteria for 'readiness' removed them from social activities, marked them as 'favourites' and encouraged them to break reciprocal kinship ties. Undermining tenants' desire for community and equality, while they waited for rewards that failed to materialise, resulted in some of their 'best' tenants being evicted because they 'would not listen to the Administration'. ${ }^{102}$ Others lost any interest they may have had in leaving the settlement. The huts were far superior to anything on reserves and there was access to a range of services. Residents accepted that they had landlords and appreciated their benefactors, but a long history of broken promises made them wary. They took what they needed, kept those they were not comfortable with at bay and resisted decisions that overstepped the mark. ${ }^{103}$ Mrs Spratt said, 'We're happy here. Why would we want to move out with white people? We've got everyone here together' ${ }^{104}$ What residents really wanted was to stay there. They complained about the 'gambling, fighting, drinking and the Administration', but the experience of Allawah Grove and the development of a community spirit resulted in exactly what Middleton had tried to avoid. ${ }^{105}$ The residents had no desire to be assimilated. What they had learned was that they wanted to stay and create an Aboriginal community with regular houses and facilities. Ruth Kickett explained that she wanted Allawah Grove to be just an 'ordinary suburb' for 'coloured people' so she could live in a community where she was wanted, and accepted as an equal. ${ }^{106}$

99 Allawah News, October 1963, Battye 3841A/MN1246.

100 Bropho 1980: 39.

101 Bropho 1980: 39-40.

102 Oxer 1963: 187.

103 Oxer 1963: 142-146.

104 Oxer 1963: 175.

105 Oxer 1963: 175-176.

106 Oxer 1963: 169. 
The decade was marked by considerable debate about the state's responsibility for Aborigines, and after decades of family dispersal to break kinship ties, anthropologists were beginning to advocate the importance of group cohesion, but there was little support for group housing in the community or at a policy level. ${ }^{107}$ By 1965, all discriminatory legislation had been repealed, the minister was empowered to loan money for small ventures and financial responsibility for education and health had been with the respective departments since 1963. ${ }^{108}$ Training and employment opportunities were improving, but there was still no funding for the big ticket item: metropolitan housing. On average, Aboriginal households accommodated more than 14 people and many people still slept under bridges or moved between camps. ${ }^{109}$ With the State Housing Commission waiting list for standard, two-bedroom houses continuing to grow and many Aboriginal families in need of four- and five-bedroom houses, there was no relief in sight. ${ }^{110}$ As Aboriginal housing became a public issue, Gare continued to work the media. He promoted the Grove as a 'finishing school for citizenship': a unique pilot scheme for Aboriginal advancement and integration, and tried to drive public sentiment with a feature article about families living in bush shelters. ${ }^{111}$ In his role as the President of the Aboriginal Advancement Council (formerly the NWC), he also lead a deputation to the minister. ${ }^{112}$ An Aboriginal spokeswoman, Sister Connie McDonald, drew on the example of 12 large families at Allawah Grove, with long-standing connections to the metro area, to suggest an official reserve for homeless Aborigines, so that they would not be 'kicked and pushed around by police'. ${ }^{113}$ The minister anticipated the usual public backlash to a metropolitan reserve, to explain their new policy, which was to provide houses in groups of 'two or three in different suburbs'. ${ }^{114}$ The introduction of this retrograde 'salt and pepper' policy was, however, yet another policy without funding or any indication of when it would be implemented.

However, shortly before the landmark referendum of 27 May 1967, and the spotlight on the national Aboriginal Welfare Conference in Perth, two families were rehoused. ${ }^{115}$ Media coverage a fortnight later depicted a domestic idyll, but there was no prospect of further housing. Having waited years, the AGA tried to push the government by issuing an ultimatum that they would hand over responsibility in six months. The DNW argued that Allawah Grove was in

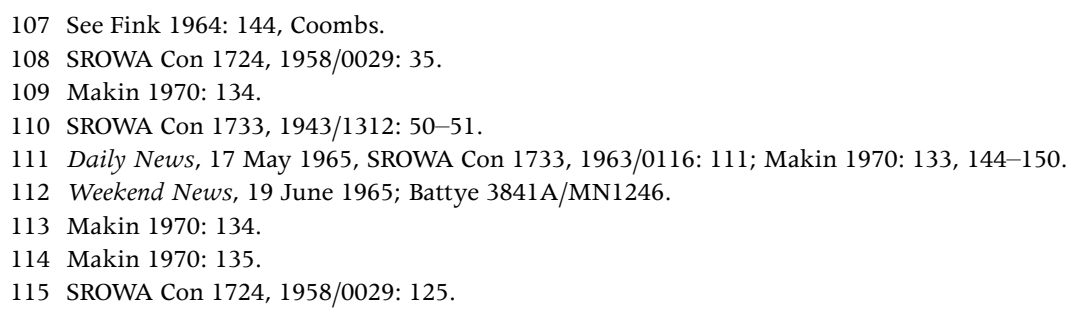


such poor condition that any expenditure could not be justified and asked for a year to locate 'appropriate' land for 'suitable tenants' ${ }^{116}$ The NWC agreed to remain until December 1968, but when the usual public and council opposition stymied the Department's efforts, Gare formed another committee to press for a special annual housing grant. ${ }^{117}$ Meanwhile, the Department had refused to rehouse anyone who was not an official tenant in November 1967. ${ }^{118}$ Elsie Gare appealed to the Director of Child Welfare out of concern for children whose parents were not on the list:

The tenant is a deserted defacto wife with 8 children under twelve years of age. She has her mother, who cares for another grandchild from a broken home ... They are under notice of eviction because no rent has been paid since February. Electricity has been disconnected ... two other related families are sheltering in the three room hut. One family with five children ... have come from West Perth where they say their home has been bulldozed for the Mitchell Freeway. The other family has come to the city because employment is easier to obtain here than in Pinjarra, they have four pre-school children.

You will see there are eighteen children involved in this one case. There are strong family ties, and separating the children from parents for institutional care does not seem to be the correct answer ... This household I have described is not an isolated case. ${ }^{119}$

Former minister Jack Brady offered support for his constituents by arguing that women with large families were 'hardly likely to be granted tenancies'. But Minister Edgar Lewis (1962-1971) drew on the new rhetoric of 'integration' and 'self-reliance' to counter that there was nothing 'to prevent native families fending for themselves'. ${ }^{120} \mathrm{He}$ added:

Everything possible is being done to find conventional houses for those families capable of making proper and effective use of them. However there are some families ... which have made no apparent progress in their social standards in all the years that they have been there and it would jeopardise the department's whole housing scheme to place such families in standard housing in the ordinary community. ${ }^{121}$

Elsie Gare warned that some families would need significant support to adjust to suburban living, so it beggars belief that the very people least able to secure state housing could 'fend for themselves' in the private market. ${ }^{122}$

\footnotetext{
116 SROWA Con 1733, 1963/0116: 166; SROWA Con 1733, 1959/0186; Daily News, 16 October 1967.

117 SROWA Con 1733, 1963/0116.

118 SROWA Con 1733, 1969/0038.

1195 June 1968, SROWA Con 1733, 1969/0038.

120 The West Australian, 2 August 1968; SROWA Con 1733, 1969/0038.

121 SROWA Con 1733, 1969/0038; 1963/0116: 62.

122 SROWA Con 1733, 1969/0038.
} 


\section{Suburban housing}

Aboriginal populations had been growing fastest in metropolitan Australia where there were more jobs and increasing access to training, but it was not until 1968 that this was confirmed and the entire housing budget allocated to the metropolitan area. ${ }^{123}$ As a result, 40 adults and 90 children from Allawah Grove were rehoused in the outer suburbs at Balga, Hamilton Hill, Coolbellup and Gosnells. ${ }^{124}$ Remarkably, the minister accused the seven families who remained without water, electricity or sanitation of 'presumably hoping to jump the housing queue'. ${ }^{125}$ Professor Berndt and Jack Davis used the press to explain that the site would become an unofficial camping ground when more people arrived for the grape-picking season and, in a public stand-off, Gare refused to demolish huts until alternative accommodation was provided. The minister threatened to bulldoze the site, until adverse publicity 'forced' him to 'consider' finding homes, 'if they could satisfy the Department of their willingness to pay rent and to care for a house'. ${ }^{126}$ Eventually, everyone was rehoused, but Clements was dismayed that families were 'dispersed all around the metropolitan area without any follow up ... in what must have been a pretty traumatic experience for them'. ${ }^{127}$ Indeed, many families left their small suburban houses or were evicted, and in 1977 the Commissioner for Community Relations reflected: 'Though much criticised in its time, [Allawah Grove] appears to have kept its inhabitants happier than they were later under Swan River bridges and in abandoned houses. ${ }^{\prime 28}$ The Department has also since acknowledged that the 'salt and pepper' policy was a failure. ${ }^{129}$

Allawah Grove was the first non-institutional settlement with individual housing in the state. It existed at a time that demanded a housing policy response, but was funded as a temporary, palliative solution that provided shelter for hundreds of people who would otherwise have been homeless in an increasingly urbanised landscape. Allawah Grove offered an opportunity to promote the conditions of possibility for Aboriginal self-determination in the metropolitan area of Perth, but it was largely left to the auspices of charities and volunteers. Between them they provided significant welfare initiatives that were taken up elsewhere as well as important training for health, education and welfare professionals. But Allawah Grove was not allocated adequate resources to address the legitimate aspirations for decent housing and meaningful participation in housing choices

123 SROWA Con 1724, 1958/0029: 188

124 SROWA Con 1733, 1969/0038.

125 The West Australian, 8 January 1969; SROWA Con 1733, 1969/0038.

126 SROWA Con 1733, 1969/0038.

127 Clements 1989: 49-50.

128 The West Australian, 8 September 1977.

129 Craig Somerville, Battye Library, pers comm, 12 April 1990. 
and homemaking, because there was little respect for, or understanding of, Aboriginal culture or recognition of their urban disadvantage. Allawah Grove was therefore largely administered by middle-class wadjelas whose aspirations for Aborigines were confined to successful integration within the wider community. It was publicly presented as a 'training settlement', an 'experiment in assimilation' and a 'pilot project'. Allawah Grove presented an opportunity to implement the rhetoric of self-direction and participation, but opportunities and consultation was limited and residents were eventually 'bulldozed' into the white community at a time when the concept of self-determination was beginning to be uttered, but not yet understood. ${ }^{130}$ Allawah Grove is but one example of a missed opportunity in urban Australia to close the gap between policies that purported to include Aborigines within the broader community as autonomous social and economic equals, and their implementation.

\section{References}

\section{Archival sources}

\section{State Records Office of Western Australia (SROWA)}

Aboriginal Housing Residential Reserves, SROWA Con 2607, A0864 V1, 2607.

Allawah Grove Accounts and Stores Correspondence, SROWA Con 1733, $1959 / 0187$.

Allawah Grove Building, Equipment and Sanitation, SROWA Con 1733, $1959 / 0186$.

Allawah Grove Education and Vocational Guidance, SROWA Con 1733, $1959 / 0198$.

Allawah Grove General Correspondence, SROWA Con 1733, 1963/0116 and 1733/1969/0038.

East Perth Area - Native Matters, SROWA Con 1733, 1943/1312.

Native camps in the metropolitan area - reports by Head Office Inspector, SROWA Con 993, 1937/0105.

Native Housing Project Allawah Grove Coolbaroo League Scheme, SROWA Con 993, 1957/0515 and 993, 1958/0321.

Publicity Press Release Publication, SROWA Con 1724, 1958/0029. 
Reserve for Natives - Guildford, SROWA Con 993, 1931/0158.

Battye Library

Allawah Grove Administration 1958-1978, 3841A/ MN1246, Battye Library.

Clements, Margaret 1989, Interview with Janice Gothard Transcript, OH 2309 Battye Library.

Gare, Elsie 1989, Interview with Janice Gothard Transcript, OH22310 Battye Library.

\section{Government publications}

Morgan, K. I. 1972, 'Aboriginal Housing - Western Australia - 1946-1971' in Aboriginal Housing The Royal Australian Institute of Architects, Canberra, February 10-11.

Western Australia. Commissioner of Native Welfare, Annual Reports, Dept of Native Welfare, Perth.

\section{Newspapers}

The Daily News

Sunday Times

The West Australian

Weekend Mail

\section{Secondary sources}

Barwick, Diane 1964, 'The self-conscious people of Melbourne', in Aborigines Now, Marie Reay (ed.), Angus and Robertson, Sydney: 20-31.

Beresford, Quentin 2006, Rob Riley: An Aboriginal Leader's Quest for Justice, Aboriginal Studies Press, Canberra.

Berndt, Catherine H. 1962, 'Mateship or success: An assimilation dilemma', Oceania 33(2): 71-89.

Berndt, Ronald M. and Catherine H. (eds) 1979, Aborigines of the West, University of Western Australia Press, Perth.

Bropho, Robert 1980, Fringedweller, Alternative Publishing Co-operative, Sydney. 
Carter, Jennie 1986, Bassendean: A Social History 1829-1979, Bassendean Town Council, Perth.

Delmege, Sharon 2000, 'The Fringedweller's Struggle: Cultural Politics and the Force of History', PhD thesis, Murdoch University.

2005, 'A trans-generational effect of the Aborigines Act 1905 (WA): The making of the Fringedwellers in the south-west of Western Australia', ELaw-Murdoch University Electronic Journal of Law 12(1).

2014, 'Camp life to suburbia: Aboriginal housing in Perth', Australian Historical Studies 45(3): 368-387.

Fink, Ruth 1964, 'Guided social change at the community level', in Aborigines Now, Marie Reay (ed.), Angus and Robertson, Sydney.

Gale, Fay 1964, 'Administration as guided assimilation (South Australia)', in Aborigines Now, Marie Reay (ed.), Angus and Robertson, Sydney.

Gale, Fay and Joy Wundersitz 1982, Adelaide Aborigines: A Case Study of Urban Life 1966-1981, Development Studies Centre, The Australian National University, Canberra.

Habibis, Daphne, Rhonda Phillips, Peter Phibbs and Julia Verdouw 2014, Progressing Tenancy Management Reform on Remote Indigenous Communities, AHURI Final Report No. 223, Australian Housing and Urban Research Institute, Melbourne.

2015, Identifying Effective Arrangements for Tenancy Management Service Delivery to Remote Indigenous Communities, AHURI Positioning Paper No. 165, Australian Housing and Urban Research Institute, Melbourne.

Haebich, Anna 2005, 'Nuclear, suburban and black: Middleton's vision of assimilation for Nyungar families', in Contesting Assimilation, Tim Rowse (ed.), API Network, Curtin University: 201-220.

2008, Spinning the Dream, Fremantle Arts Centre Press, Fremantle.

Hasluck, Paul 1988, Shades of Darkness, Melbourne University Press, Melbourne.

Hodson, Sally 1989, 'Nyungahs and Work: Aboriginal Labour in the Great Southern Region, WA 1936-1972', MA Diss, University of Western Australia.

Howard, Michael C. 1981, Aboriginal Politics in Southwestern Australia, UWA Press, Perth.

Keen, Ian (ed.) 1988, Being Black: Aboriginal cultures in Settled Australia, Aboriginal Studies Press, Canberra. 
Kinnane, Stephen 2003, Shadow Lines, Fremantle Arts Centre Press, Fremantle.

Langton, Marcia 1981, 'Urbanizing Aborigines: the social scientists' great deception', Social Alternatives 2(2): 16-22.

Makin, Clarence F. 1970, 'A Socio-Economic Anthropological Survey of People of Aboriginal Descent in the Metropolitan Region of Perth, Western Australia', PhD thesis, University of Western Australia.

Manning, Corinne 2005, "If Aborigines are to be assimilated they must learn to live in houses": Victoria's transitional Aboriginal housing policy', in Contesting Assimilation, Tim Rowse (ed.), API Network, Curtin University: 221-236.

Milligan, Vivienne, Rhonda Phillips, Hazel Easthope and Paul Memmott 2010, Service Directions and Issues in Social Housing for Indigenous Households in Urban and Regional Areas, AHURI Positioning Paper No. 130, Australian Housing and Urban Research Institute, Melbourne.

2011, Urban Social Housing for Aboriginal People and Torres Strait Islanders: Respecting Culture and Adapting Services, AHURI Final Report No. 172, Australian Housing and Urban Research Institute, Melbourne.

Morgan, George 2000, 'Assimilation and resistance: Housing Indigenous Australians in the 1970s', Journal of Sociology 36(2): 187-204.

Oxer, Rosemary 1963, 'Allawah Grove: An Experiment in Assimilation', Hons thesis, University of Western Australia.

Pearson, Noel 2000, Ben Chifley Memorial Lecture, Bathurst Panthers Leagues Club, 12 August.

Rowley, Charles 1970, The Destruction of Aboriginal Society, Australian National University Press, Canberra.

—1972, Outcasts in White Australia, Penguin, Sydney.

Rowse, Tim 2005, 'The post-war social science of assimilation 1947-1966', in Contesting Assimilation, Tim Rowse (ed.), API Network, Curtin University, Perth: 151-168.

Sanders, Will 2008, 'Equality and difference arguments in Australian Indigenous affairs: Examples from income support and housing', CAEPR Working Paper No. 38, Centre for Aboriginal Economic Policy Research, Canberra. 
SWALSC (South West Aboriginal Land and Sea Council), John Host and Chris Owen 2009, It's Still in My Heart, This is My Country, University of Western Australia Press, Perth.

Taffe, Susan 1995, 'Australian diplomacy in a policy vacuum: Government and Aboriginal Affairs, 1961-62', Aboriginal History 19(2): 154-172.

Walley, Robyn Smith and Tracie Pushman 2005, On the Outskirts: Photographs of Allawah Grove Aboriginal Settlement, Perth, University of Western Australia Press, Perth.

Wilson, J. 1964, 'Assimilation to what?', in Aborigines Now, Marie Reay (ed.), Angus and Robertson, Sydney: 151-166. 
This text is taken from Aboriginal History, Volume 39, 2015, edited by Liz Conor, published 2015 by ANU Press,

The Australian National University, Canberra, Australia. 